\title{
Detection of Sub Clinical Mastitis Pathogens by Multiplex PCR
}

\author{
Kavita Jaidiya*, Anju Chahar, T. C. Nayak and Mahaveer Suresha
}

Department of Epidemiology and preventive Veterinary Medicine, College of Veterinary and Animal Science, Rajasthan University of Veterinary and Animal Sciences, Bikaner -334001, Rajasthan, India

*Corresponding author

\section{Keywords}

Asymptomatic, Dairy herds, Staphylococcus aureus, Streptococcus agalactiae

Article Info

\section{Accepted:}

17 January 2021 Available Online: 10 February 2021

\section{A B S T R A C T}

A total of 200 quarter milk samples from 50 apparently healthy cows were examined by mPCR. In present study, the quarter wise prevalence of Sub clinical mastitis in cows 46.5 per cent (93/200) based on mPCR, respectively. Animal wise prevalence of sub clinical mastitis in cows was 52 per cent (26/50) based on mPCR. On examination Staphylococcus spp. (42 per cent) being major pathogen. Organism isolated in mixed infections was Streptococcus spp., Klebsiella pneumoniae, E. coli and Pseudomonas aeruginosa.

\section{Introduction}

Mastitis is one of the most important disease of bovines and continues to have a major economic impact in the dairy industry through out the world (Bachaya et al., 2012). Mastitis is classified into clinical and sub clinical form, according to degree of inflammation and severity of disease (Awale et al., 2012). The sub clinical mastitis is asymptomatic, therefore milk appears to be normal. This form of mastitis is + 30-40 times more common than clinical mastitis and causes the great loss in most of the dairy herds. Sub clinical mastitis is devasting disease in dairy industry through out the world and in India it is enzootic and alarming. The sub clinical mastitis usually goes unnoticed because the milk and udder appear normal. The sub clinical mastitis is mainly caused by

Staphylococcus aureus, Streptococcus agalactiae and Streptococcus species and coliform (Mpatswenumugabo et al., 2017). The $S$. aureus is the major pathogen of sub clinical mastitis (Piepers et al., 2007). The Multiplex Polymerase Chain Reaction (mPCR) for mastitis diagnosis is helpful for rapid application of the preventive measures of the disease (Qing-Hil et al., 2008). 


\section{Materials and Methods}

A total of 200 quarter milk samples from 50 apparently healthy cows of different lacteal stage were collected aseptically from LRS, College of Veterinary and Animal Science, Bikaner and private dairies in surrounding areas of Bikaner. All the milk samples were screened by multiplex PCR.

\section{Collection of milk samples}

Milk samples were collected aseptically. Udder and teats were washed with water and air dried. Then each teat was wipped off by spirit swab. First Two three strippings of fore milk were discarded. Approximately $30 \mathrm{ml}$ of fore milk from each teat was collected in sterilized test tube with caps. These were marked as right fore (RF), right hind (RH), left fore (LF), left hind (LH). Care was taken to avoid any type of contamination in the milk.

The milk samples from a total of 200 quarters of 50 cattle collected in the present study. All the samples of milk were brought to the laboratory and kept in refrigerator $\left(4^{\circ} \mathrm{C}\right)$ until analysed. Milk samples were subjected to mPCR.

\section{Multiplex PCR}

Multiplex PCR helps in rapid detection and identification for more than one bovine mastitis pathogens at a time. The use of multiplex PCR resulted in identification of bacterial DNA of mastitis pathogens in culture negative milk samples also (Koskine et al., 2010).

\section{Procedure}

Multiplex PCR helps in rapid detection and identification for more than one bovine mastitis pathogens at a time. The use of multiplex PCR resulted in identification of bacterial DNA of mastitis pathogens in culture negative milk samples also (Koskine et al., 2010)

\section{Isolation of DNA from mastitic milk}

DNA isolation from mastitic milk samples was done by using Thermo scientific DNA extraction kit, following protocol supplied with the kit.

\section{Agarose gel electrophoresis}

Agarose gel electrophoresis was carried out in horizontal submerged electrophoresis unit. It is used to check the integrity of DNA. For electrophoresis, 0.8 per cent agarose gel in TBE buffer containing ethidium bromide (0.5$1 \mu \mathrm{g})$ was used. After addition of bromophenol blue dye, each sample was loaded in the well of gel. $100 \mathrm{~V}$ at room temperature was required to carried out electrophoresis for about 1-2 $\mathrm{hr}$ depending upon the length of gel or till the dye migrated more than half of the length of the gel. At the end of electrophoresis, the gel was visualized under UV transilluminator and photographs were obtained.

\section{Genotyping}

Following sets of primers were used for species level confirmation of the isolates multiplex PCR.

\section{Set No-1}

\section{Bacterial species Product size}

Staphylococcus aureus $\quad 264 \mathrm{bp}$

Pseudomonas aeruginosa $\quad 472 \mathrm{bp}$

Klebsiella pneumoniae $\quad 555 \mathrm{bp}$

Annealing temperature for following set of primers was $55^{\circ} \mathrm{C}$. 
Table.1 Reaction preparation for species multiplex PCR set no.1.

\begin{tabular}{|c|c|c|}
\hline S.No. & PCR components & Quantity \\
\hline $\mathbf{1}$ & $5 \times$ PCR assay buffer & $5 \mu 1$ \\
\hline $\mathbf{2}$ & Mgcl2 & $3 \mu 1$ \\
\hline $\mathbf{3}$ & dNTP & $1 \mu 1$ \\
\hline $\mathbf{4}$ & Primer- Frwd & $1 \mu 1$ \\
\hline $\mathbf{5}$ & Primer- reverse & $1 \mu 1$ \\
\hline $\mathbf{6}$ & Taq DNA polymerase & $0.25 \mu 1$ \\
& $(5$ U/ $\mu$ l) & $3 \mu 1$ \\
\hline $\mathbf{7}$ & Template DNA & $6.75 \mu l$ \\
\hline $\mathbf{8}$ & DEPC treated & $\mathbf{2 5 \mu l}$ \\
\hline
\end{tabular}

Table.2 Steps in species specific multiplex PCR reaction

\begin{tabular}{|c|c|c|c|}
\hline Step & & Temperature $\left({ }^{\circ} \mathbf{C}\right)$ & Time \\
\hline Step 1 & Denaturation & 96 & $5 \mathrm{~min}$ \\
\hline Step 2 & Denaturation-Annealing-Set & 94 & $1 \mathrm{~min}$ \\
( 35 cycle) & 1 & 55 & $1 \mathrm{~min}$ \\
& Set 2 & 51 & $1 \mathrm{~min}$ \\
& Set 3 & 51 & $1 \mathrm{~min}$ \\
& Extension & 72 & $1 \mathrm{~min}$ \\
\hline Step 3 & Final extension & 72 & $7 \mathrm{~min}$ \\
& Hold & 4 & infinite \\
\hline
\end{tabular}

Table.3 Relative frequency of different types of bacterial isolates in sub clinical mastitits infected quarters by $\mathrm{m}$ PCR

\begin{tabular}{|c|c|c|c|}
\hline S.No & Bacterial isolates & No. of quarters & Percentage (\%) \\
\hline $\mathbf{1}$ & Staphylococcus aureus & 39 & 41.93 \\
\hline $\mathbf{2}$ & Streptococcus agalactiae & 11 & 11.8 \\
\hline $\mathbf{3}$ & Staphylococcus hyicus & 8 & 8.69 \\
\hline $\mathbf{4}$ & Streptococcus uberis & 4 & 4.30 \\
\hline $\mathbf{5}$ & Klebsiella pneumoniae & 6 & 6.45 \\
\hline $\mathbf{6}$ & Escherichia coli & 6 & 6.45 \\
\hline $\mathbf{7}$ & Streptococcus dysgalactiae & 8 & 8.69 \\
\hline $\mathbf{8}$ & Staphylococcus epidermidis & 2 & 2.15 \\
\hline $\mathbf{9}$ & Pseudomonas aeruginosa & 1 & 1 \\
\hline $\mathbf{1 0}$ & $\begin{array}{c}\text { Streptococcus aureus+ } \\
\text { Streptococcus dysgalactiae }\end{array}$ & 3 & 3.22 \\
\hline $\mathbf{1 1}$ & $\begin{array}{c}\text { Staphylococcus aureus }+ \text { Escherichia } \\
\text { coli }\end{array}$ & 2 & 2.15 \\
\hline $\mathbf{1 2}$ & $\begin{array}{c}\text { Staphylococcus aureus }+ \\
\text { Streptococcus agalactiae }\end{array}$ & 2 & 2.15 \\
\hline $\mathbf{1 3}$ & $\begin{array}{c}\text { Staphylococcus aureus }+ \text { Klebsiella } \\
\text { pneumonia }+ \text { Pseudomonas } \\
\text { aeruginosa }\end{array}$ & 1 & \\
\hline & Total & & \\
\hline & $\quad$ & & \\
\hline
\end{tabular}


Table.4 Pathogens detected by Multiplex PCR

\begin{tabular}{|c|c|c|}
\hline S.No & Bacterial pathogens & Number of organism \\
\hline $\mathbf{1}$ & Staphylococcus aureus & $47(46.07$ per cent $)$ \\
\hline $\mathbf{2}$ & Streptococcus agalactiae & $13(12.74$ per cent $)$ \\
\hline $\mathbf{3}$ & Staphylococcus hyicus & $8(7.84$ per cent $)$ \\
\hline $\mathbf{4}$ & Klebsiella pneumonia & $7(6.86$ per cent $)$ \\
\hline $\mathbf{5}$ & E.coli & $8(7.84$ per cent $)$ \\
\hline $\mathbf{6}$ & Streptococcus uberis & $4(3.92$ per cent $)$ \\
\hline $\mathbf{7}$ & Streptococcus dysglactiae & $11(10.7$ per cent $)$ \\
\hline $\mathbf{8}$ & $\begin{array}{c}\text { Staphylococcus } \\
\text { epidermidis }\end{array}$ & $2(1.96$ per cent $)$ \\
\hline $\mathbf{9}$ & Pseudomonas aeruginosa & $2(1.96$ per cent $)$ \\
\hline & Total & $\mathbf{1 0 2}$ \\
\hline
\end{tabular}

Fig.1 Relative frequency of different types of bacterial isolate in sub clinical mastitis infected quarters by mPCR (Sample having single infection)

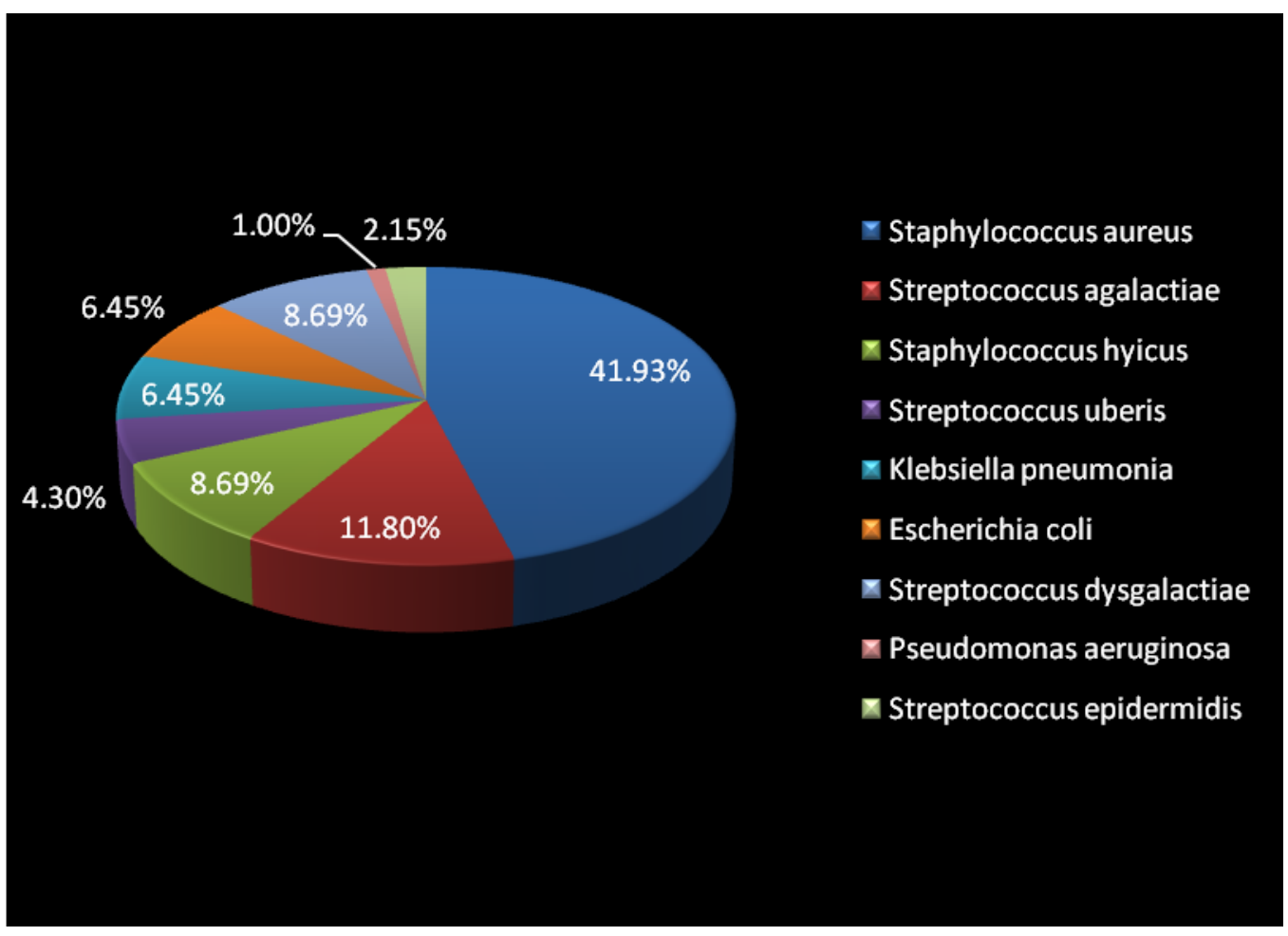


Fig.2 Relative Frequency 93 isolates from 82 quarters by mPCR

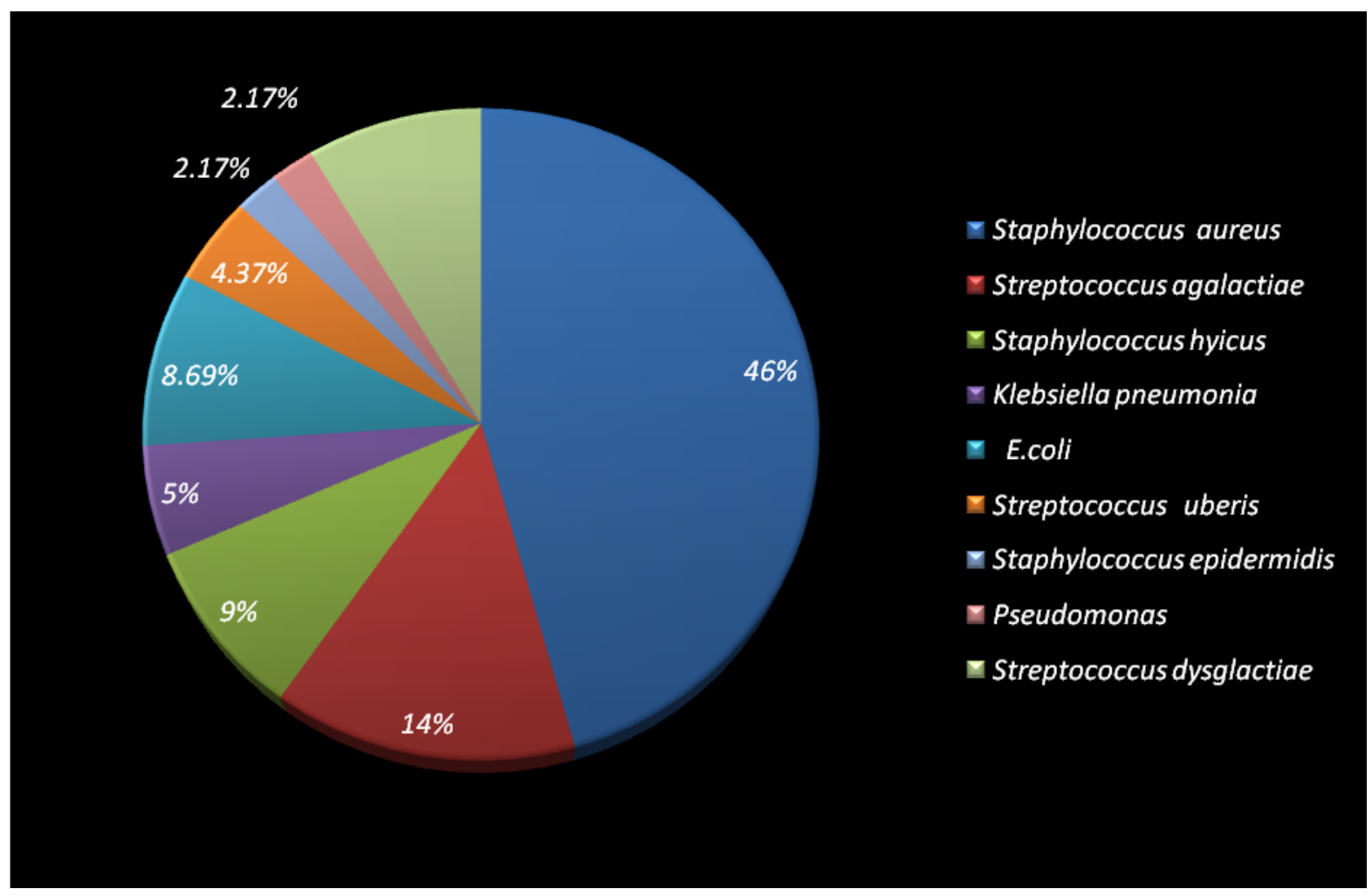

Fig.3 Set-1 Identification of Staphylococcus aureus-264bp Klebsiella pneumoniae-555 bp and Pseudomonas aeruginosa 472 bp

\section{B1 B2 B3 B4 B5 B6 B7 Bs B9 B10 B11 B12 M}

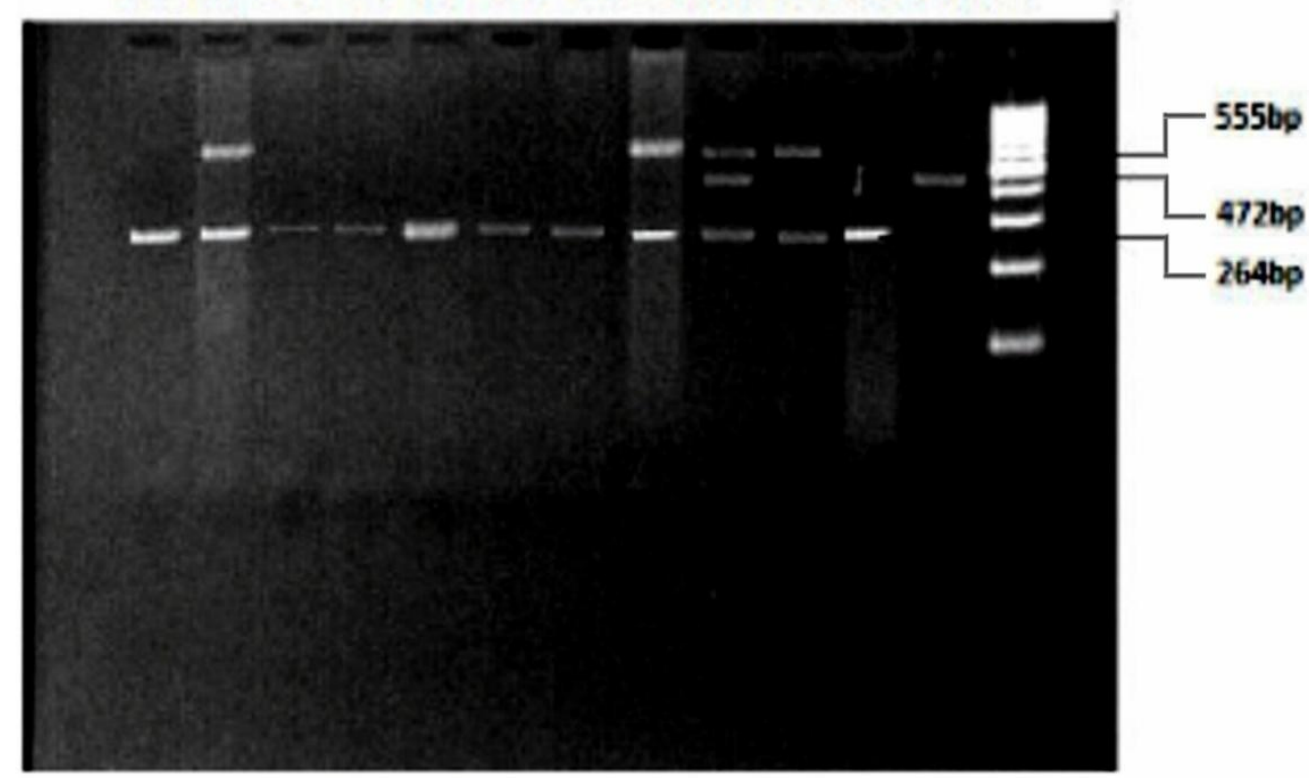


Fig.4 Set 2 - Identification of E. coli-119bp Streptococcus agalactiae-304bp amplicon size

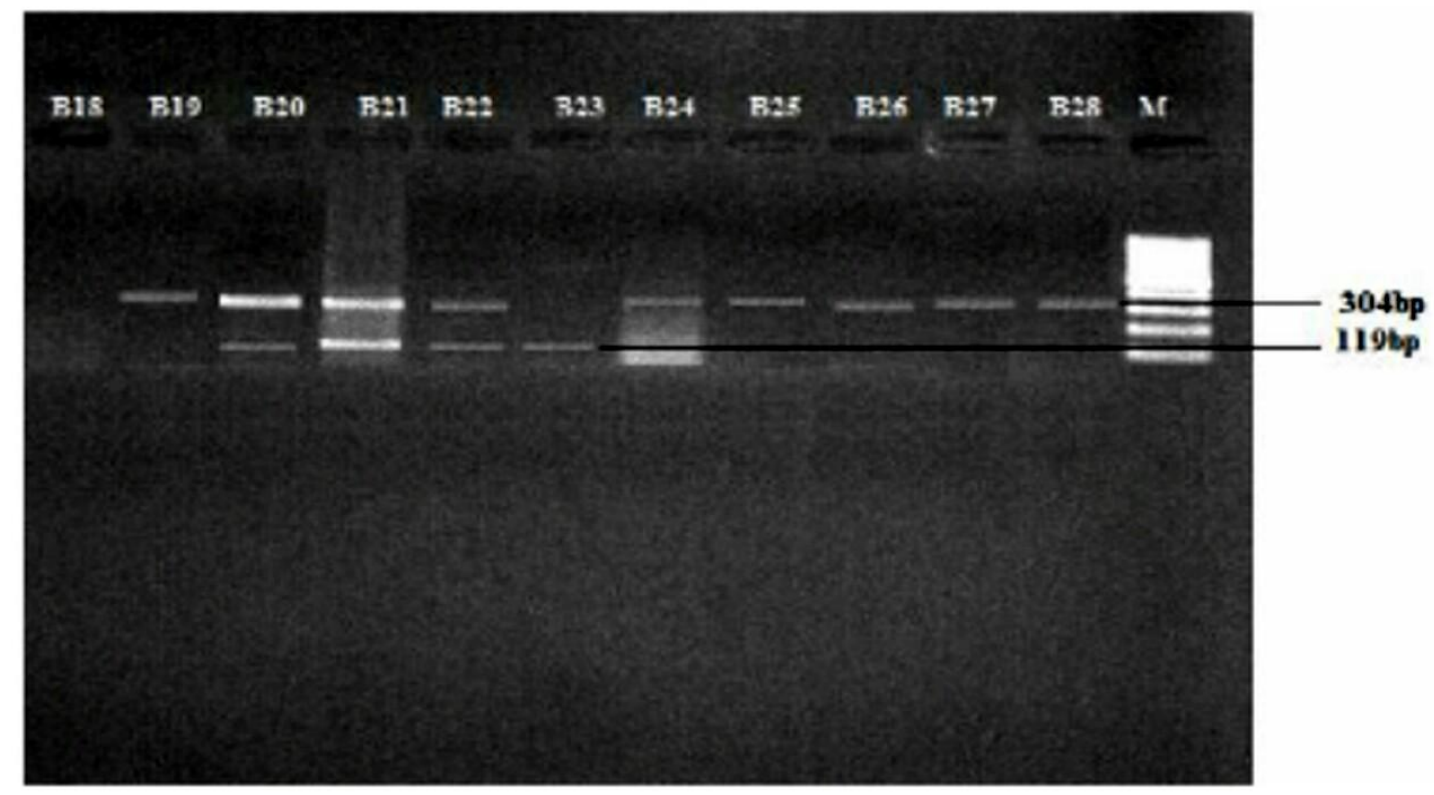

Fig.5 Set 3 Identification of Staphylococcus hyicus-173bp, Streptococcus uberis-338bp

\section{B25 B26 B27 B28 B29 B30 B31 B32 B33 B34 B35 B36 B37 B38 B39 M}

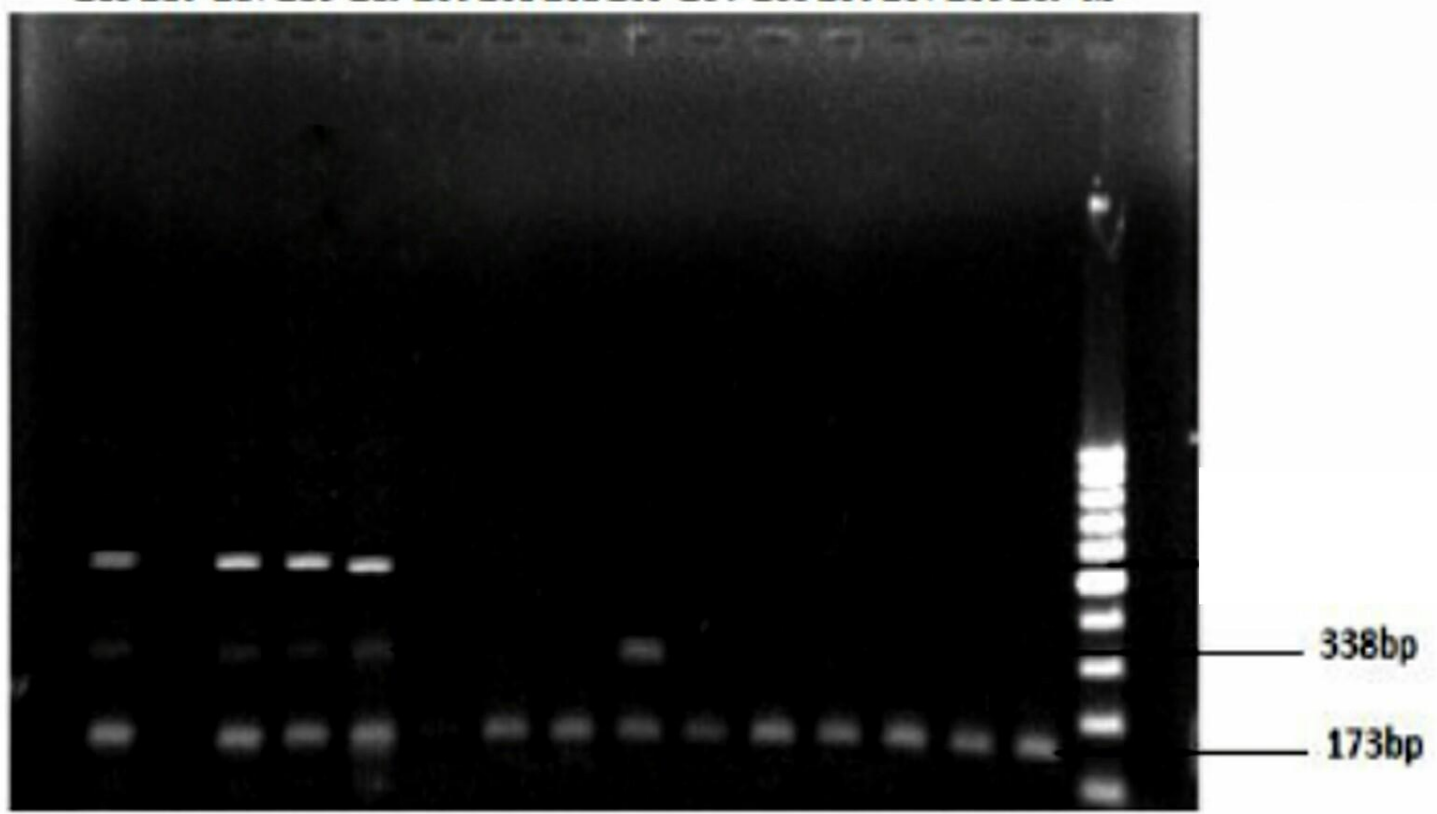


Vick gene based identification of Atr gene based identification of Listeria Staphylococcus aureus monocytogenes

Js SA F- 5CAGACCGTCGTGGACGTATT jsStrAg 3

CCCTTCTGGCTCTGGTAAGTC 3

$\begin{array}{llllll}\text { JS } & \mathrm{SA} & \mathrm{R} & \mathrm{jsStrAg} & \mathrm{R}- & 5\end{array}$

5`TCACGTCATGTAACACAGGGA 3` TGCTGGATAAGCATTAGCCTTCT 3`

FecR gene based identification of Set No- 3

Pseudomonas aeuroginosa

$\begin{array}{lllll}\text { Js } & \text { PA } & \mathrm{F} & - & 5\end{array}$

TGACCACGAAGAACACCTCG 3`

Bacterial species product size

Staphylococcus hyicus $173 \mathrm{bp}$

Js $\quad$ PA $\quad$ R- 5 Streptococcus uberis 338bp

TTCGCAGACGAAACCGAAGA 3`

Bar A gene based identification of Klebsiella pneumoniae

Js KN F- 5`GATGGGCGGGGATATTTCGT 3

Js KNR- 5`TTCAGGTTAGCCGGGTTGTC 3

Annealing temperature for following set primers was $51^{\circ} \mathrm{C}$.

Sod A gene based identification of Staphylococcus hyicus

Js SH F- 5 TAACAATGGTGGCGGTCACT 3

Js SH R- 5`AAGCCCAGCCAGATCCAAAT

Set No. 2 3

Bacterial species product size

pauA gene based identification of Streptococcus uberis

Escherichia coli $\quad 119 \mathrm{bp}$

Streptococcus agalactiae 304bp

jsStrU F- 5

AACTAGTCGACTTTGCGCCT3`

Annealing temperature for following set of primers was $51^{\circ} \mathrm{c}$

jsStrU R- 5

GTCAGGGTAGCGTTGCAAAA3`

Uid A gene based identification of Multiplex Polymerase Chain Reaction Echerichia coli

(Table no.- 1)

Js $\quad$ EC $\quad F \quad-5 ` \quad$ Results and Discussion

TACCGACGAAAACGGCAAGA 3’

Js EC R- 5`CGGTGATATCGTCCACCCAG 3

Out of 200 quarters milk samples, 93 quarters were found positive for pathogenic bacteria on mPCR. Out of 93 samples, 102 bacterial 
isolates were identified in which $85(91.3 \%)$ milk samples were having single bacterial infection where as $8(8.60 \%)$ milk samples were having mixed infection (Fig. 1-5 and Table 2). Organisms isolated in mixed infections were Staphylococcus spp., Streptococcus spp., Klebsiella spp., E. coli. and Pseudomonas. (Table-3 and 4)

The findings of present study are similar with Choudhary (2018) who isolated 97 isolates from 40 clinical mastitis samples by mPCR, out of that $S$. aureus was maximum $(62.5 \%$, 25/97) followed by $S$. agalactiae $(42.5 \%$, 17/97), S. hyicus (35\%, 14/97), K. pneumonia (32\%, 13/97), E. coli $(25 \%, 10 / 97)$, S. uberis (12.5\%, 5/97), P. aerugenosa (12.5\%, 5/97), L. monocytogenes $(5 \%, 2 / 97)$ and $M$. bovis (15\%, 6/97), respectively. The multiplex PCR in present study provided a convenient and accurate identification of 9 important mastitis pathogens simultaneously.

The multiplex PCR successfully detected all those bacteria isolated in culture studies. It was helpful in detecting the organisms even in culture negative samples.

Taponen et al., (2009) reported a large proportion of positive samples via molecular methods from culture-negative milk samples in conventional bacteriology.

The present study entitled "Studies on some aspects of sub clinical mastitis in cattle" was undertaken to determine the prevalence of subclinical mastitis in cattle on the basis of California mastitis test, cultural examination and mPCR, changes in composition of milk and oxidative stress in animals having sub clinical mastitis.

Out of 200 quarters milk samples, 93 were found positive for pathogenic bacteria on mPCR. Out of 82 samples, 102 bacterial isolates were identified in which 85 milk samples were having single bacterial infection $(91.39 \%)$, where as $8(8.60 \%)$ milk samples were having mixed infection. Organisms isolated in mixed infections were Staphylococcus spp., Klebsiella spp., E. coli and Pseudomonas aeruginosa.

For identification of organism cultural method is time consuming. Therefore, multiplex PCR analysis should be used which helps in rapid detection and identification for more than one bovine mastitis pathogens at a time that could produce results in a single day with the help of species specific primers.

\section{References}

Awale, M.M., Dandhatra, G.B., Avinash, K. Chauhan, B.N., Modi, C.M., and O' Kennedy, R. (2012) Bovine mastitis: a threat to economy. Open Access Scientific Reports, 1(15): 295.

Bachaya, A., Raza, M.A. and Akbar, R. (2011). Sub clinical bovine mastitis in Muzaffar Garth district of Punjab (Pakistan). Journal of Animal Sciences, 21(1): 16-19.

Khelef, D., Saidi, R. and Kaidi, R. (2013). Bovine mastitis: Prevalence of bacterial pathogens and evaluation of early screening test. African journal of microbiology Research., 7(9): 777782.

Koskine, M.T., Wellenberg, G.J and Sampimon, O.C. (2010) Field comparison of real time PCR and bacterial culture for identification of bovine mastitis. Journal of Dairy Science, 93(12): 5707-5715.

Mpatswenumugabo, J.P., Bebora, L.C., Gitao, G.C., Moblegi, V.A., Iraguha, B. Kamana, O., Gitao, G.C., Mobegi, V.A., Shumbusho, B. (2017). "Prevalence of subclinical Mastitis and Distribution of pathogens in Dairy farms of Rubare and Nyabihu Districts, 
Rawanda. Journal of Veterinary Medicine, pp 8.

Piepers, S., Meulemeester, L. De., Kruit, A. De, Opsomer, G., Barkema. H.W., and Vliegher S.De., 2007. Prevalence and distribution of mastitis pathogens in subclinically infected dairy cows in Flanders, Belgium, Journal of Dairy Research., 74: 478-483.

Quing- Hill, M.A,: Zhou, Y.U., Feng, L.I. and
Ping, L. (2008). Progress on Sub clinical mastitis in Dairy cows. Progress in Veterinary Medicine.

Taponen, S., Salmikivi, L., Simojoki, H., Koskinen, M.T. and Pyorola, S. (2009) Real-time PCR based identification of bacteria in milk samples from bovine clinical mastitis with no growth in conventional culturing. Journal of Dairy Science, 92(6): 2610-2617.

\section{How to cite this article:}

Kavita Jaidiya, Anju Chahar, T. C. Nayak and Mahaveer Suresha. 2021. Detection of Sub Clinical Mastitis Pathogens by Multiplex PCR. Int.J.Curr.Microbiol.App.Sci. 10(02): 21802188. doi: https://doi.org/10.20546/ijcmas.2021.1002.259 